\title{
A new Oligocene leaf assemblage from the Ghalandar area (NW Iran) and its contribution to understanding of floristic evolution in the eastern Paratethys
}

\author{
ZLATKO KVAČEK \& MIROSLAV BUBÍK
}

\begin{abstract}
The geological survey in NW Iran (Ahar area, Ghalandar village) carried out by the Czech Geological Survey in the years 2007-2009 provided new data on the geology, coal petrography and palaeobotany of this part of the eastern Paratethys. The recovered plant impressions, dated by radiometric ages of associated volcanic rocks to the Oligocene, have been identified as Osmunda parschlugiana (Unger) Andr., Picea (sect. Omorika) sp., cf. Magnolia sp., Eotrigonobalanus furcinervis (Rossm.) Walther \& Kvaček, cf. Acer aegopodifolium (Göpp.) Baik. and Dicotylophyllum subpeltatum Kvaček sp. nov. The site characterizes a new floristic assemblage ("complex") Ghalandar in the eastern Paratethys, which differs from the Oligocene broad-leaved evergreen floristic assemblage of Dilizhan previously defined from the Caucasus area by the mixed-mesophytic character of forest vegetation. - Key words: flora, Oligocene, eastern Paratethys, Iran.
\end{abstract}

KVAČEK, Z. \& BUBíK, M. 2016. A new Oligocene leaf assemblage from the Ghalandar area (NW Iran) and its contribution to understanding of floristic evolution in the eastern Paratethys. Bulletin of Geosciences 91(4), $705-715$ (6 figures). Czech Geological Survey, Prague. ISSN 1214-1119. Manuscript received August 3, 2016; accepted in revised form December 5, 2016; published online January 13, 2017; issued February 7, 2017.

Zlatko Kvaček, Charles University, Faculty of Science, Institute of Geology and Palaeontology, Albertov 6, 12843 Praha 2, Czech Republic; kvacek@natur.cuni.cz・Miroslav Bubík, Czech Geological Survey, Leitnerova 22, 60200 Brno, Czech Republic; miroslav.bubik@geology.cz

Palaeofloristic evolution in the eastern Paratethys during the Oligocene has long been a focus of interest of Russian palaeobotanists (e.g. Kryshtofowicz 1928, Zhilin 1989), because this area, although not explored in detail, brought clues for changes from subtropical towards temperate vegetation types ("Arcto-tertiary hypothesis" of Engler 1879) during the Paleogene. Mai (1995, pp. 312-321) gave a summary of this topic in a detailed analysis including all fossil floras in question. He recognized two main zones playing in their development the most important role: the Tethyan zone and the Boreal zone (Mai 1995, pp. 326-331). For the eastern Paratethys (Caucasus area) he characterized during the Oligocene a single floristic Dilizhan assemblage ("complex") of the broad-leaved evergreen, laurophyllous character, in which evergreen Fagaceae, mainly Eotrigonobalanus furcinervis (Rossm.) Walther \& Kvaček, dominated (e.g. Kolakovsky \& Arutjunjan 1969) together with another extinct fagaceous element Trigonobalanopsis, legumes and palms (Kasumova 1966; Mai 1995, pp. 412-413). Intriguing questions have arisen when and where this evergreen type of vegetation transitioned to mixed-mesophytic and mostly deciduous forest types occurring in the Oligocene of the adjacent areas in Kazakhstan ("Turgayan" type sensu Kryshtofowicz). Sites of Paleogene plant assemblages, which may address these questions, are located either in Kazakhstan or in western Azerbaijan in the territory of the former Soviet Union (Kasumova 1966, Zhilin 1974). None is available beyond these areas.

During the geological survey mapping (in 1:25,000 scale) conducted by the Czech Geological Survey for the Geological Survey of Iran in the years 2007-2009 macrofossil plant remains were encountered in Oligocene ash tuffs near Ghalandar village in the Ahar area, northwestern Iran (Otava et al. 2011). During two short visits a small collection of fossil plants was recovered and brought to the Czech Republic for later determination and evaluation. Although limited in its diversity, this flora represents a novelty in the palaeofloristic development of this part of the eastern Paratethys.

\section{Geological setting}

The wider area of northwestern Iran with the Alborz and Talesh mountains (Fig. 1) is a part of the collision zone of 


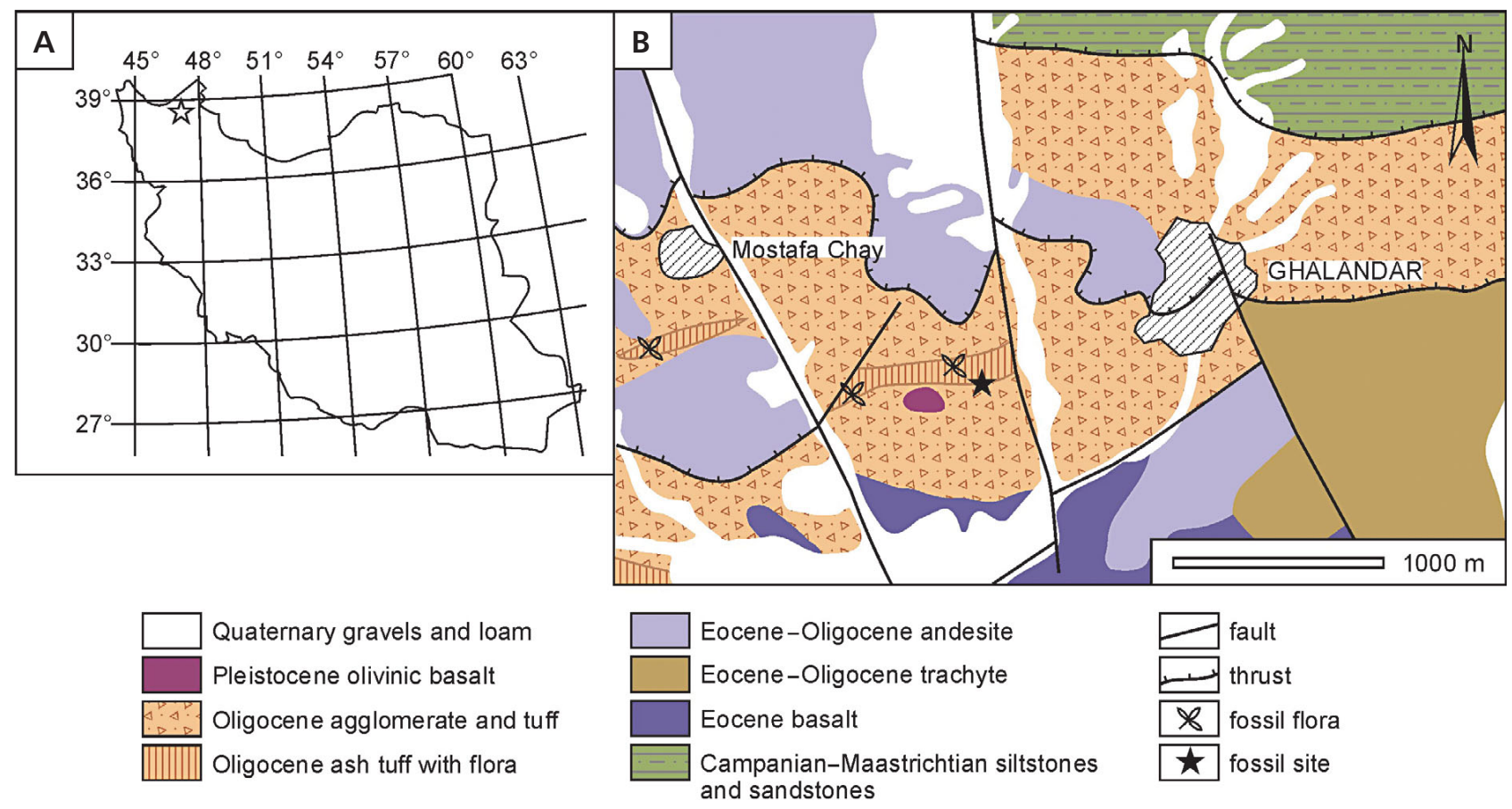

Figure 1. A - position of the fossil site on map of Iran indicated by asterisk. • B - detail geological map of Ghalandar vicinity (after Otava et al. 2011, modified).

the Iranian Microplate pushed by the Eurasian Plate to the NE and the Arabian Plate to the SW. This zone is bordered by sutures resulting from the Tethyan arc-arc collision at the NE and by the Tethyan continent-arc collision at the SW (Alavi 1991, Axen et al. 2001).

The Alborz and Talesh mountains are built of rocks that originated in the Palaeo-Tethys oceanic realm (Neoproterozoic-Triassic) as well as in the Tethys (Jurassic-Cenozoic) that underwent deformation during the Cimmerian and Alpine orogenies. Metamorphic complexes, sedimentary rocks and magmatic assemblages form either single thrust sheets or complex duplex systems which were transported generally from the NNE to the SSW along numerous thrust faults (Alavi 1996).

According to Lescuyer et al. (1978) the Ahar city area (including Ghalandar) is a part of the East Azerbaijan volcanic plateau bordered by the folded zone on the North and by the Mehraban Neogene basin on the South. The East Azerbaijan plateau includes metamorphic complexes of uncertain age, Cenozoic volcanic and plutonic rocks, folded Cretaceous-Paleogene marine sediments and Neogene continental basins.

The immediate surroundings of the Ghalandar city illustrate well the complex geological history of the area. The oldest rocks form a metamorphic complex of unknown age (gneisses, schists and amphibolites). The Upper Cretaceous (Turonian-Maastrichtian) comprises grey rudist limestones, marly limestones with inoceramids, red cherty limestones, grey marlstone flysch and volcano-sedimen- tary facies with andesitic and basaltic lavas and their volcaniclastics. The Paleocene is represented by oceanic red beds (claystones) and by flysch facies. The Eocene is characteristic by intensive andesitic to basaltic volcanism and volcano-sedimentary facies with hyaloclastites and both coherent and pillow lavas.

Cretaceous to early Oligocene rocks are deformed and overthrusted in the form of nappes as consequence of a major tectonic event around the middle of the Oligocene. The extensive intrusion of monzonites and syenites with a suite of abundant sills and subvolcanic bodies was also related to this event. Products of effusive trachytic and trachydacitic volcanism cover folded older units with angular unconformity. They comprise agglomerate, lapilli and ash tuffs and ignimbrites co-magmatic with the intrusions of plutonic rocks as apparent from complete silicate analyses. $\mathrm{K}-\mathrm{Ar}$ age of volcanic rocks, obtained during the geological survey in the years 2007-2009 varies around 26 Ma corresponding to an age of Chattian (Otava et al. 2011, Rapprich et al. 2012).

In the Miocene the Alborz Mountain was uplifted and any Miocene rock record in the wider Ahar area is lacking. During the Pliocene-Pleistocene large intermountain basins filled by continental clastic sediments originated there.

Trachydacitic tuffs from which the plant fossils were recovered are part of the late Oligocene magmatic association. At closer view they can be described as whitish, grey and yellowish fine-grained ash tuffs. Graded bedding, small slump folds and flame structures indicate re-sedi- 
mentation of the ash into aquatic conditions. These reworked tuffs possess higher preservation potential for plant macrofossils. Besides leaf and twig impressions, fragments of charcoal as well as pieces of silicified tree trunks were encountered. Fragments of silicified wood reveal the plant-bearing horizon within the tuffs at a distance over $1 \mathrm{~km}$.

In the road cut near the fossil site thin lenses of coal $50 \mathrm{~cm}$ in diameter were observed (Fig. 2). The coal can be characterized as inertinite, vitrinite and semifusinite. Organic matter is partly replaced by silica, which fills the cell voids of wood tissue (J. Franců, personal communication).

\section{Material and method}

The fossil plants were collected from a site $800 \mathrm{~m}$ west-south-west of the Ghalandar village, north of the

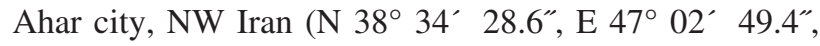
$1,650 \mathrm{~m}$ above sea level). On the gentle slope fine-grained ash tuffs with plant remains were exposed in flat outcrops and also pieces of silicified tree trunks were observed on the surface (Fig. 3).

The samples studied represent impressions of foliage and twigs preserved in yellow-bedded ash tuff. Due to weathering process some impressions are partly dark brown to reddish, most others represent whitish impressions. Neither remains of leaf substance nor any traces of cuticles were observed on fossils. Hence the identification proceeded on the basis of gross morphological characters preserved.

\section{Systematic palaeobotany}

The plant elements, identified and described below, belong to one fern, one conifer, monocots and several broad-leaved dicots. Due to a limited number and fragmentary nature of samples, unambiguous determinations have been only rarely achieved.

Ferns

Family Osmundaceae Martinov

\section{Genus Osmunda Linnaeus subg. Osmunda}

\section{Osmunda parschlugiana (Unger) Andreánszky}

Figure 4A, B

Material. - Incomplete pinnule, MB 10b.

Description. - Fragmentary apical part of a pinnule $11 \mathrm{~mm}$ wide, incomplete in length (preserved impression $40 \mathrm{~mm}$

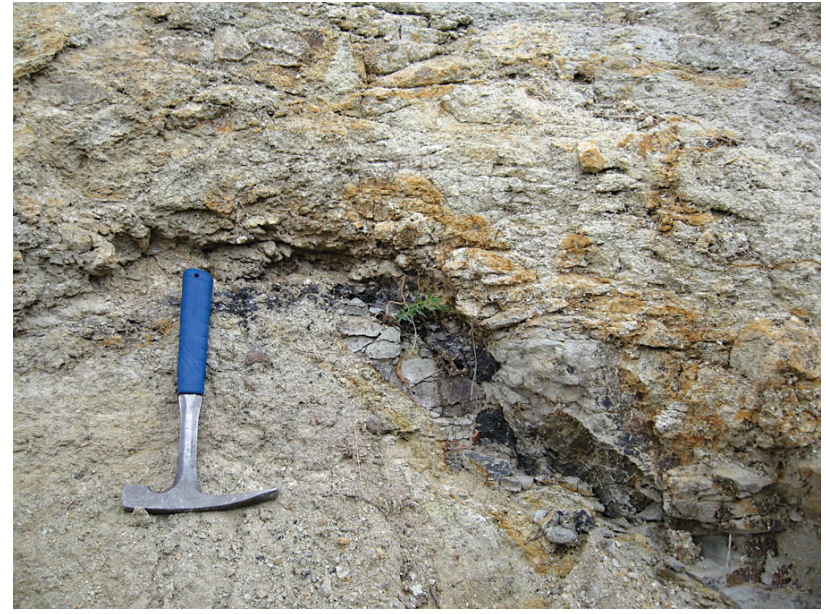

Figure 2. Coal lens enclosed within trachydacitic tuff, Ghalandar village, NW Iran.

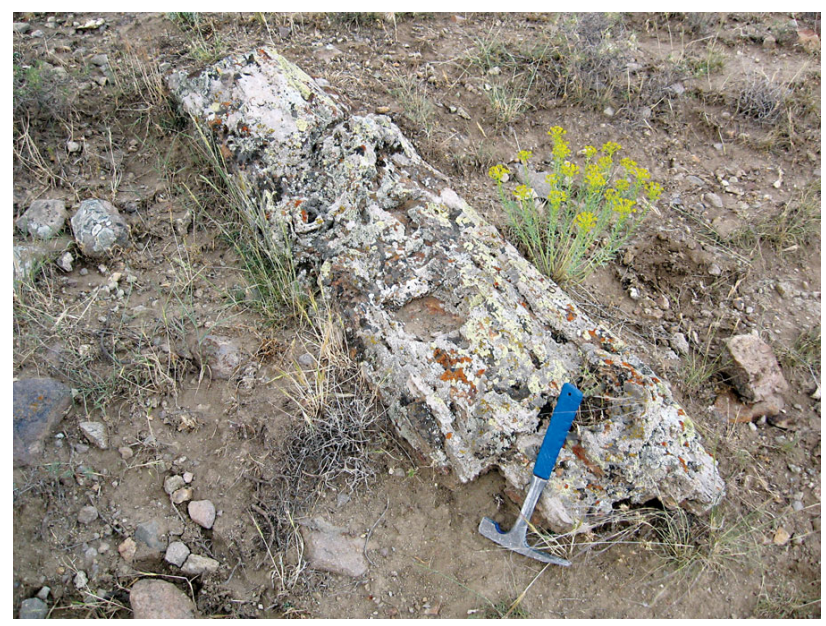

Figure 3. Silicified tree trunk in the horizon of trachydacitic tuffs near Ghalandar village, NW Iran. Length of trunk is about $2 \mathrm{~m}$.

long), straight narrow ovate, blunt on tip, sub-entire on margin, midrib thin, slender and straight, secondary veins densely spaced (at $0.4-0.8 \mathrm{~mm}$ ), simple as well as once or twice forked near the midrib or rarely again slightly higher, at an angle of $c a 50-40^{\circ}\left(-30^{\circ}\right.$ near pinnule tip).

Remarks. - This fern was probably mentioned (without illustrations) in the Oligocene plant assemblages of the adjacent region of the Lesser Caucasus (Kasumova 1966, p. 6) under various names, e.g. Pteris parschlugiana Unger, Pteris pennaeformis Heer, Osmunda heerii Gaudin, but we were unable to verify the identifications by inspection of the collected specimens. Similar foliage remains are known also in the Oligocene of Kazakhstan, e.g. at Ashutas (Kryshtofowicz et al. 1956, p. 45, pl. 1, figs 1, 2, text-fig. 5a-ž, as Osmunda doroshiana Göpp.), Bukhtarma (Rajushkina 1979, p. 52, pl. 15, fig. 6, as Osmunda heerii 
Gaudin) and elsewhere associated with the Turgayan ("Arcto-tertiary") leaf assemblages. Although sterile and fragmentary, the affinity of the above described single impression to Osmunda subg. Osmunda is evident.

Records assigned to different fossil species of Osmunda subg. Osmunda from the early Paleogene, e.g. O. sachalinensis Krysht. (Paleogene of eastern Asia Borsuk 1956, Tanai 1970), O. macrophylla Penhallow (Paleogene of the Arctic - Boulter \& Kvaček 1989, Budantsev \& Golovneva 2009) do not differ essentially and conform the venation pattern of recent $O$. regalis Linnaeus. Occurrences of Osmunda parschlugiana are spread in Europe in wetland vegetation of many Miocene sites (Hably 2013) and rarely cross the Oligocene-Miocene boundary avoiding plant assemblages of warm climatic zones called the mastioixoid floras.

Conifers

Pinaceae Lindl.

Picea A. Dietr. sect. Omorika Willk.

\section{Picea sp.}

Figure 4C-E

Material. - Twigs and needles, MB 1 to 4.

Description. - Twigs widely alternately ramified, up to $3 \mathrm{~mm}$ thick, densely covered by distinct helically disposed peg-like rhomboid cushions (pulvini), mostly devoid of needles, exceptionally with solitary needles attached, detached needles dispersed close to twigs, needles truncate at base, acute at apex, flat, 1-1.6 mm wide, slightly more than $20 \mathrm{~mm}$ long.

Remarks. - This conifer matches in the sculpturing of twigs the pattern, which is very characteristic of spruce, particularly well-developed pulvini, which help to distinguish Picea from other genera of the Pinaceae (LePage 2001). Our collection corresponds in the morphology of dorsiventrally flattened needles to Picea sect. Omorika. Neither other organs nor details of leaf anatomy have been recovered associated.

Fossil macrofossils of spruce have been described from the Oligocene of Kazakhstan (Picea altaica Rajushkina, Picea mugodzharica Rajushkina, Picea sp.Rajushkina 1968, 1979). Contrary to the above-described fossils, these records are related to sect. Picea and show the quadrangular cross section of needles. The available material does not preserve necessary details of sterile twigs to be compared with all other fossil representatives of spruce based on foliage (for the review see LePage 2001).

\section{Angiosperms}

Family Magnoliaceae Juss.

\section{Genus Magnolia L.}

\section{cf. Magnolia sp.}

Figure $5 \mathrm{~A}-\mathrm{C}$

Material. - Leaf impression and counter-impression, MB 6a, b.

Description. - The lower part of a large oblong leaf more than $60 \mathrm{~mm}$ wide and much over $120 \mathrm{~mm}$ long, base entire-margined, narrow rounded and at very base truncate to shallowly sub-cordate, venation brochidodromous, midrib straight, medium thick, secondary veins at base denser, almost perpendicular to the midrib, higher secondary veins mostly regularly spaced and dense, almost straight, simple, at angles of $c a 40^{\circ}$ slightly increasing proximally, forked and looping close to margin; intersecondaries absent, tertiary venation vaguely visible, sinuate, forked.

Remarks. - Similar large leaves with the entire margin and dense regular secondary venation are not common in the fossil state. Some were recognized as magnolias, e.g. Magnolia schaarschmidtii Walther, 2003 in the Eocene of the Weisselster Basin, Germany or M. maii Walther, 2003 in the Oligocene of Saxony, both with the preserved epidermal anatomy. They both differ from the above-described specimen in the broader leaf form and M. maii by the distinctly cordate base. A definite determination of the leaf would require epidermal characteristics. Impressions of this sort may also be produced by Lauraceae and Fagaceae [e.g. Eotrigonobalanus furcinervis (Rossm.) Walther \& Kvaček - see below]. Several living magnolias with deciduous foliage produce leaves similar to the above-described fossil, mainly of sect. Buergeria (Sieber \& Zucc.) Baill., e.g. M. salicifolia (Sieber \& Zucc.) Maxim. distributed in Japan.

Figure 4. A, B - Osmunda parschlugiana (Unger) Andreánszky. $\bullet$ A - fragmentary pinnule, MB $10 \mathrm{~b}, \mathrm{scale}$ bar $=10 \mathrm{~mm}$. $\bullet$ B - magnified detail of the previous figure showing venation, scale bar $=5 \mathrm{~mm}$. $\bullet \mathrm{C}-\mathrm{E}-$ Picea $\mathrm{sp} . \cdot \mathrm{C}-$ twig without needles, MB 1 , scale bar $=10 \mathrm{~mm}$. $\bullet$ D - twig with an attached needle, MB 3A, scale bar $=10 \mathrm{~mm} . \bullet \mathrm{E}-$ dispersed fragmentary twigs and detached needles, $\mathrm{MB} 3 \mathrm{~B}$, scale bar $=10 \mathrm{~mm}$. 

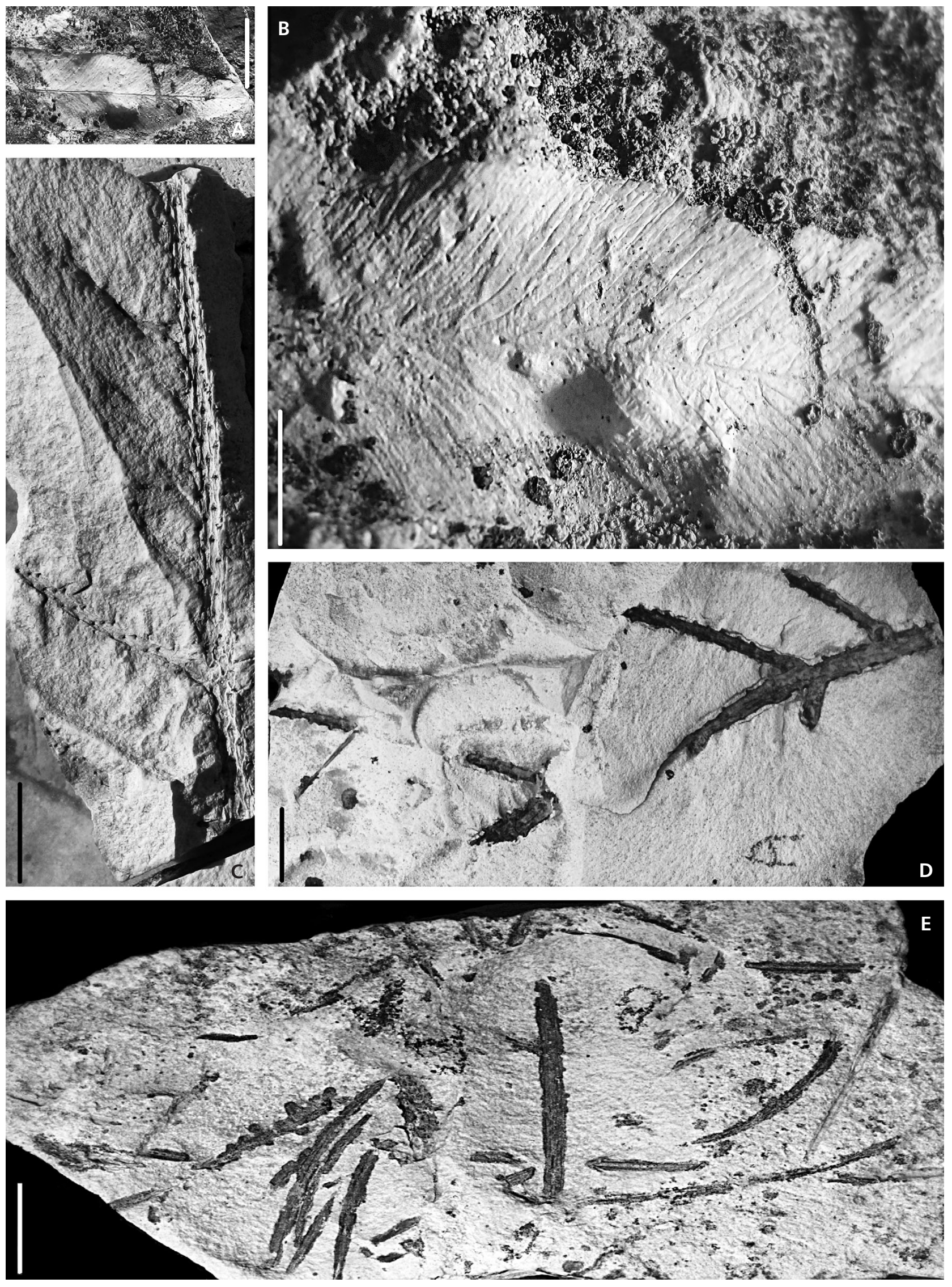
Family Cyperaceae Juss.

\section{Genus Cyperacites Schimper}

\section{Cyperacites sp.}

Figure 5C

Material. - Leaf impressions, MB 10c, others not catalogued.

Description. - Fragments of linear leaves, 2-4 mm wide, slightly revolute at margin and with a medial shallow grove; fine parallel venation obscured by fossilization.

Note. - Such narrow monocotyledonous leaves preserved as leaf impression material are not determinable to the natural system of monocots and, nomenclaturally, are usually treated only as form taxa. Schimper (1870-1872) correctly replaced the name of the fossil genus Cyperites Lindley \& Hutton (based on foliage of Sigillaria) by Cyperacites Schimper, formally typified by $C$. dubius (Heer) Schimper (see Andrews 1970, p. 67). This fossil taxon requires a wider study. The above-described fragments correspond to several fossil species listed in Schimper (1870-1872) and described by Heer (1855, p. 79, pl. 29, fig. 3 - Lausanne; Heer 1869 , p. 28 , pl. 3 , figs 15 b, 17 , pl. 12 , fig. 17 - Svetlogorsk etc.) from the Paleogene deposits of Europe. The affinity of the fragments at hand to living monocotyledons is obvious but determination of a more exact systematic position is out of question.

Family Fagaceae Dum.

\section{Genus Eotrigonobalanus Walther \& Kvaček}

\section{Eotrigonobalanus furcinervis (Rossm.) \\ Walther \& Kvaček}

Figures 6A, B

Material. - Leaf impression and counter-impression, MB 5.

Description. - Leaf elliptic, incomplete, $30 \mathrm{~mm}$ wide, more than $60 \mathrm{~mm}$ long, simple dentate, base rounded, slightly asymmetrical, apex missing, venation semicraspedodromous, midrib straight, thick secondary veins mostly regularly spaced, at an angle of $\mathrm{ca} 45^{\circ}$ slightly increasing proximally, forked in the second third of the length or slightly closer to the margin, tertiary venation not visible.

Remarks. - Leaves of Eotrigonobalanus are the most characteristic angiosperm foliage at numerous European late Paleogene sites (see Mai \& Walther 1985, as Dryophyllum furcinerve, Kvaček \& Walther 1989). The leaves vary considerably from entire-margined to coarsely dentate and show a characteristic epidermal anatomy. This plant element is common in the Oligocene plant assemblages of the Caucasus and adjacent areas [Kasumova 1966 - as Quercus furcinervis (Rossm.) Unger, Q. vetusta Kassumova, Q. talyschensis Kassumova; Kolakovsky \& Arutjunjan 1969 - designated as Castanopsis furcinervis (Rossm.) Kräusel \& Weyland].

Family Sapindaceae Juss.

\section{Genus Acer L.}

\section{cf. Acer aegopodifolium (Göpp.) Iljinskaja}

Figure 6C, D

Material. - Leaf fragment, MB 10a.

Description. - An incomplete fragment of lobate or compound leaf with only one lobe (leaflet?) preserved, lamina coarsely bluntly dentate, $15 \mathrm{~mm}$ wide, $30 \mathrm{~mm}$ long, apex acuminate, base missing, venation craspedodromous, slightly asymmetrical, midrib slightly S-shaped, secondary veins irregularly widely spaced, bent towards apex, at an angle of about $40^{\circ}$ or less, partly forked, reaching the tooth apex. Tertiary vein fabric irregular reticulate, epimedial tertiary veins almost perpendicular to slightly acute to the midrib. Higher-order venation obscure.

Remarks. - The described fossil leaf fragment is very incomplete and the determination must remain doubtful. The asymmetrical base and rounded as well as triangular teeth on margin correspond well with the morphology of leaflets of Acer aegopodifolium as illustrated from the Upper Oligocene-Lower Miocene of Ustjurt (Zhilin 1974, pl. 40, figs 5-7).

This maple probably immigrated from Asia to Europe later during the Miocene. These new fossils have been suitable to verify the systematic position by epidermal anatomy (see Schmitt \& Kvaček 1999, Walther \& Zastawniak 2005). On account of detailed venation, Kovar-Eder (1988)

Figure 5. cf. Magnolia sp. • A - fragmentary leaf, MB 6A, scale bar $20 \mathrm{~mm}$. • B - magnified basal part of the previous figure, scale bar $10 \mathrm{~mm}$. Cyperacites sp. $\bullet \mathrm{C}-$ leaf fragment, $\mathrm{MB} 10 \mathrm{C}$, scale bar $=5 \mathrm{~mm}$. 


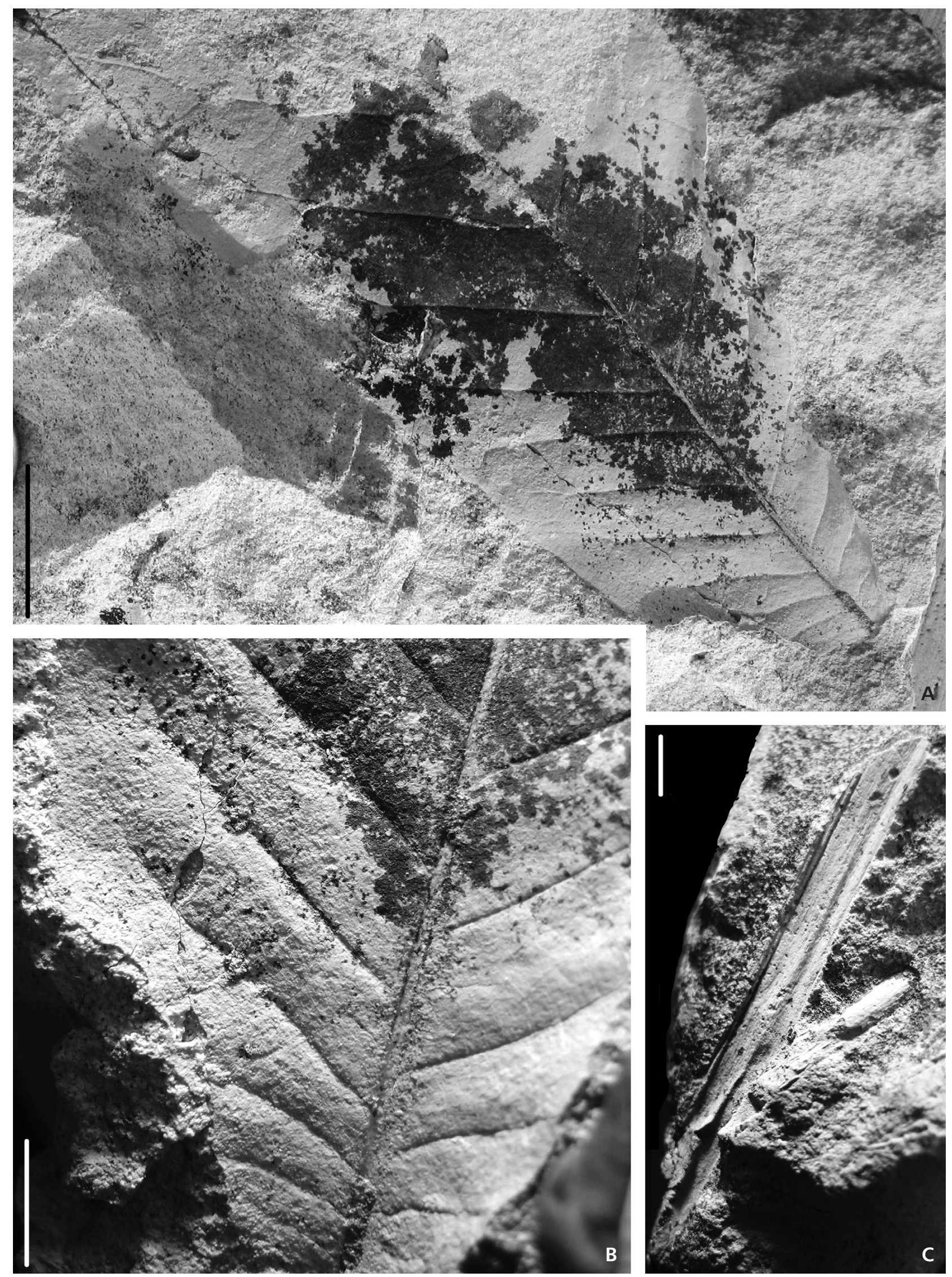


recognized the affinity of Acer aegopodifolium to sect. Trifoliata.

Angiosperms fam. inc.

\section{Genus Dicotylophyllum Saporta}

\section{Dicotylophyllum subpeltatum sp. nov.} Figure 6E-H

Holotype - Leaf impression, MB 8a (Fig. 6E), coll. Czech Geological Survey, Praha.

Paratypes. - Leaf impressions, MB 8b, c, MB 9 (Fig. 6F, H), coll. Czech Geological Survey, Praha.

Etymology. - According to the leaf base.

Description. - Leaves simple and entire-margined (?), incomplete (without apices), lamina at base more than $60 \mathrm{~mm}$ wide, widely rounded, sub-peltate, venation palmate, primary vein framework basal, midrib straight, lateral primary veins 2 on either side, radiating from the base at an angle of 40 to $45^{\circ}$, apically slightly bent, secondary veins eucamptodromous, parallel, widely spaced, tertiary veins very distinct, intercostal percurrent alternate, epimedial mixed percurrent, higher-order venation reticulate, areoles $c a 0.3 \mathrm{~mm}$ in diameter, free ending veinlets absent.

Remarks. - The available material is very incomplete. The surface of one slab shows several large leaf impressions, which are partly overlapping in a manner recalling foliage of an aquatic plant floating on the water surface. This accumulation may have arisen accidentally in sedimentation of low energy in standing water. None of the leaf specimens is completely preserved as a whole leaf and all lack petiole. A very distinctive tertiary venation allows recognizing individual even fragmentary specimens of the same fossil species.

Similar leaf morphotypes have been assigned to Populus L., e.g. P. jarmolenkoi (Iljinskaja) Iljinskaja from the late Oligocene flora of Ashutas, $P$. parapacifica Chelebaeva from the Oligocene and Neogene of the Far East - see Iljinskaja in Arbuzova et al. (2005) or P. germanica (Menzel) Walther in Mai \& Walther (1978) from the Oligocene of Germany. They all differ from D. subpeltatum in the petiolate leaf base with a flattened petiole and partly toothed margin. The distinct venation preserved in tuff on an unevenly spread lamina agrees with a presumed soft texture and deciduous character of foliage. We meet similar difficulties in assessing systematic affinities as in the case of D. semipeltatum (Rossm.) Knobloch \& Kvaček from the late Eocene Staré Sedlo flora of north Bohemia (Knobloch et al. 1996). Foliage with similar venation patterns was reported from the Eocene of Europe (Messel, Kučlín, Lábatlan) as Byttneriopsis Kvaček \& Wilde, 2010, and interpreted on account of epidermal anatomy and co-occurrence of seeds as fossil malvalean plants.

\section{Palaeoenvironment}

The late Oligocene plant assemblage of Ghalandar suggests existence of a forested area, in which broad-leaved trees prevailed. Due to equable representation of both evergreen and deciduous elements, the reconstructed vegetation cover corresponds to the mixed mesophytic forest type. We are unable to support our judgment by a statistical calculation because diversity of the plant assemblage is too low. The proximity of lignite layers indicates humid palaeoclimatic conditions with a moderate annual precipitation without a pronounced dry season. In general, the Ghalandar plant assemblage supports the palaeoclimatic estimations suggested by Akhmetiev (Akhmetiev \& Zaporozhets 1992, Akhmetiev in Popov et al. 2009) for the northern Caucasus and Kazakhstan, i.e. Mean Annual Temperature $13-20^{\circ} \mathrm{C}$ and Annual Precipitations to $1000 \mathrm{~mm}$.

\section{Relations to other Paleogene plant assemblages in the eastern Paratethys}

The collected plant material from Ghalandar consists of only a limited number of elements, which clearly differentiate this plant assemblage from the others recovered so far in the eastern Paratethys Oligocene. It belongs to a new floristic complex that differs from the previously defined one of Dilizhan (sensu Mai 1995, p. 412) in the Oligocene of the Caucasus area by the mixed-mesophytic ("Arctotertiary" or Turgay) character. This new floristic assemblage ("complex") of Ghalandar includes macrofossils of

Figure 6. A, B - Eotrigonobalanus furcinervis (Rossm.) Walther \& Kvaček. • A - fragmentary leaf, MB 5A, scale bar $=10$ mm. $\bullet$ B - counter-impression of the previous figure with a fragment of leaf shown in Fig. A, MB 5B\&A, scale bar 10 mm. • C, D - cf. Acer aegopodifolium (Göpp.) Iljinskaja. - C - leaf fragment, MB 10A, scale bar $=10 \mathrm{~mm}$. $\bullet$ D - detail of the previous figure, scale bar $=5 \mathrm{~mm}$. $\bullet$ E-H - Dicotylophyllum subpeltatum Kvaček sp. nov. $\cdot \mathrm{E}-$ a group of leaf impressions with the holotype (below), MB 8 , scale bar $=20 \mathrm{~mm}$. $\bullet \mathrm{F}-$ detail of holotype, MB $8 \mathrm{~A}$, scale bar $=10 \mathrm{~mm}$. - $\mathrm{G}$ - subpeltate leaf base, MB 7, scale bar $=10 \mathrm{~mm}$. $\cdot \mathrm{H}$ - leaf fragment with indistinctly dentate (?) margin, MB 9 , scale bar $=10 \mathrm{~mm}$. 

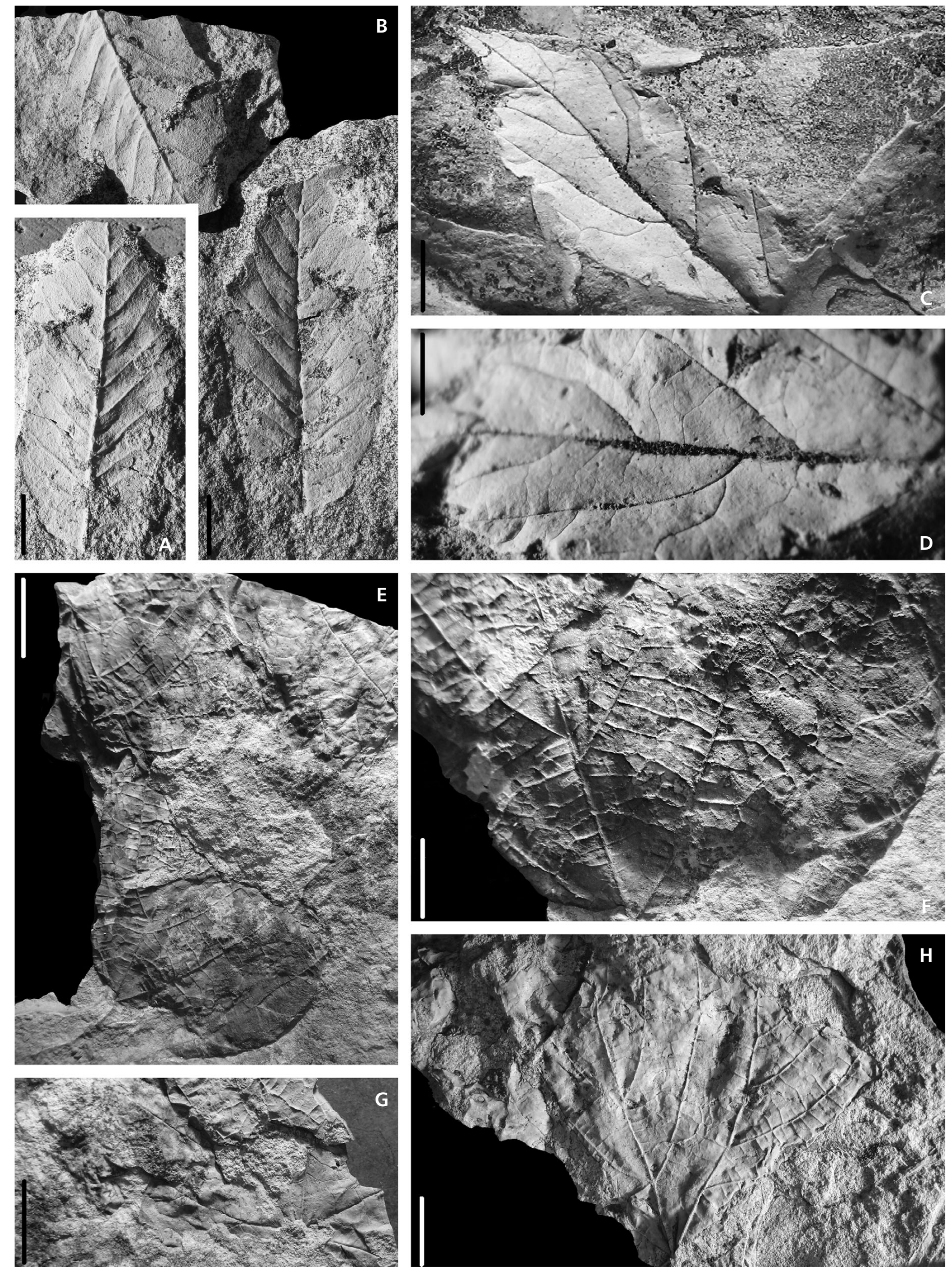
Osmunda subg. Osmunda, Picea and broad-leaved dicotyledonous elements, partly deciduous (Acer and probably Magnolia), partly evergreen (Eotrigonobalanus). In this respect it resembles much richer plant assemblages in the Zaisan area, such as Ashutas (Kryshtofowicz et al. 1956), or in the Altai Mts (Rajushkina 1979) while those from the western Azerbaijan (Kasumova 1966, Kolakovsky \& Arutjunjan 1969) are dominated by evergreen Fagaceae, mainly Eotrigonobalanus and Trigonobalanopsis, and Lauraceae. The previously overlooked occurrence of Doliostrobus (Kasumova 1966, pl. 11, fig. 11, as Cypressus sp.) connects the Indzhachai flora with the European Eocene and early Oligocene. The Ghalandar floristic assemblage fits in the Turgay (Kazakhstan) province, as characterized by Akhmetiev (in Popov et al. 2009, p. 107), connected with the warm temperate forest types described from Ustjurt, northern Pri-Aralye and Turgay (see Zhilin 1974, 1989). Our findings support the stepwise immigration of the so-called Turgay (Zhilin 1989) or "modern Arcto-tertiary" elements (Kvaček 1994) from Asia to Europe during the Paleogene.

\section{Acknowledgment}

We are indebted to Petr Budil and other collection managers of the Czech Geological Survey for the technical assistance in handling and photography of the material studied. Our colleague Vasilis Teodoridis (Prague) kindly helped with illustrations and commented on our determinations. The first author $(\mathrm{ZK})$ received financial support by the Grant Agency of Czech Republic (GAČR, Project 14-23108S).

\section{References}

AKhmetiev, M.A. \& ZAPOROZHETS, N.I. 1992. Klimaty Oligocena vostoka Krymsko-Kavkazskoi oblasti i Kazakhstana. Izvestiya Akademii nauk SSSR, Seriya geologicheskaya 1992(3), 5-23.

Alavi, M. 1991. Tectonic map of the Middle East, scale 1: 5000 000. Geological Survey of Iran, Teheran.

Alavi, M. 1996. Tectonostratigraphy synthesis and structural style of the Alborz Mountain system in northern Iran. Journal of Geodynamics 21(1), 1-33. DOI 10.1016/0264-3707(95)00009-7

ANDREws, H.N. 1970. Index of generic names of fossil plants 1820-1965. Geological Survey Bulletin 1300, 1-354.

Arbuzova, O., Chelebaeva, A., Iljinskaja, I., Proskurin, K. \& VickULIn, S. 2005. Fossil flowering plants of Russia and adjacent countries 4. Nactaginaceae-Salicaceae. 184 pp. Institutum botanicum Komarovianum Academiae scientiarum rossicae, Moskva \& Sankt Peterburg.

Axen, G.J., Lam, P.J., Grove, M., Stockli, D.F. \& Hassanzadeh, J. 2001. Exhumation of the west-central Alborz Mountains, Iran, Caspian subsidence, and collision related tectonics. $G e$ ology 29, 559-562.

DOI 10.1130/0091-7613(2001)029<0559:EOTWCA >2.0.CO;2
Borsuk, M.A. 1956. Paleogenovaya flora Sakhalina [Paleogene flora of Sakhalin]. Trudy VSEGEI, New Series 12, 1-88.

Boulter, M.C. \& KvaČEK, Z. 1989. The Palaeocene flora of the Isle of Mull. Palaeontology, Special Papers 42, 1-149.

Budantsev, L.Y. \& Golovneva, L.B. 2009. Iskopaemaya flora Arktiki II. Paleogenovaya flora Spitsbergena. 400 pp. Marafon, Sankt Peterburg.

ENGLER, A. Versuch einer Entwicklungsgeschichte der extratropischen Florengebiete der nördlichen Hemisphäre. 202 pp. Wilhelm Engelmann, Leipzig.

Hably, L. 2013. The Late Miocene floras of Hungary. Geologica hungarica, Series palaeontologica 59, 1-175.

HeER, O. 1855. Flora Tertiaria Helvetiae I. 116 pp. J. Wurster et comp., Winterthur.

HeER, O. 1869. Miozäne baltische Flora. Beiträge zur Naturkunden Preussens 2, 1-104.

Kasumova, G.M. 1966. Flora oligotsenovykh otlozheniy severo-vostochnykh predgoriy Malogo Kavkaza (Azerbaijan) $i$ yeyo stratigraficheskoe znachenie. 59 pp. Izdatelstvo Akademii nauk Azerbaidjanskoi SSR, Baku.

Knobloch, E., Konzalová, M. \& Kvaček, Z. 1996. Die obereozäne Flora der Staré Sedlo-Schichtenfolge in Böhmen (Mitteleuropa). Rozpravy Českého geologického ústavu 49, $1-260$.

Kolakovsky, A.A. \& Arutuunjan, M.E. 1969. Castanopsis furcinervis, kak kharakternyi element oligotsenovykh flor Kavkaza (Castanopsis frucinervis as a characteristic element of the Oligocene floras of the Caucasus). Izvestiya $A N$ Armjanskoy SSR, Nauki o Zemlje 2, 10-18.

Kovar-Eder, J. 1988. Obermiozäne (Pannone) Floren aus der Molassezone Österreichs. Beiträge zur Paläontologie Österreichs 14, 19-121.

KRYSHTOFOwICZ, A.N. 1928. Grendlandskaya tretichnaya flora na Severnom Urale i botaniko-geograficheskie provintsii tretichnogo perioda. Priroda 1928(25), 499-502.

Kryshtofowicz, A.N., Palibin, I.V., Shaparenko, K.K., Jarmolenko, A.V., Bajkovskaja, T.N., Grubov, V.I. \& ILJINSKAJA, I.A. 1956. Oligotsenovaya flora gory Ashutas $\mathrm{v}$ Kazakhstane [Oligocene flora of the Ashutas mountain in Kazakhastan]. Trudy Botanicheskogo instituta Akademii nauk SSSR, Series 8, Paleobotanika 1, 1-180.

KVAČEK, Z. 1994. Connecting links between the Arctic Paleocene and European Tertiary floras. NATO ASI Series 127, 251-266.

KvaČEK, Z. \& Walther, H. 1989. Revision der mitteleuropäischen tertiären Fagaceen nach blattepidermalen Charakteristiken. III. Teil. Dryophyllum Debey ex Saporta und Eotrigonobalanus Walther \& Kvaček gen. nov. Feddes Repertorium 100, 575-601.

KVAČEK, Z. \& WILDE, V. 2010. Foliage and seeds of malvalean plants from the Eocene of Europe. Bulletin of Geosciences 85(1), 163-182. DOI 10.3140/bull.geosci.1170

LePage, B.A. 2001. A new species of Picea A. Dietrich (Pinaceae) from the middle Eocene of Axel Heiberg Island, Actic Canada. Botanical Journal of the Linnean Society 135, 137-167. DOI 10.1111/j.1095-8339.2001.tb01088.x

Lescuyer, J.L., Riou, R., Babakhani, A., Alavi, T.N., Nogol, M.A., Didon, J., Gemain, Y.M. \& Amidi, M. 1978. Geological Map of Ahar, Scale $1: 250,000$ (explanatory booklet). Geological Survey of Iran, Teheran. 
MAI, D.H. 1995. Tertiäre Vegetationsgeschichte Europas. 691 pp. Gustav Fischer Verlag, Jena.

MaI, D.H. \& Walther, H. 1978. Die Floren der Haselbacher Serie im Weisselster-Becken (Bezirk, Leipzig, DDR). Abhandlungen des Museums für Mineralogie und Geologie zu Dresden 28, 1-101.

Mai, D.H. \& Walther, H. 1985. Die obereozänen Floren des Weisselster-Beckens und seiner Randgebiete. Abhandlungen des Staatlichen Museums für Mineralogie und Geologie zu Dresden 33, 1-260.

Otava, J., Bubík, M., ČeCh, S., Černý, J., Francủ, J., Havír, J., KopačKová, V., MartíneK, K., MašeK, D., Maštera, L., Opletal, M., Rambousek, P., Rapprich, V., Švábenická, L., ŽÁČeK, V., Domas, J., MilovskÝ, R. \& KrMíčEK, L. 2011. Capacity building of Geological Survey of Iran's staff in geological mapping at $1: 25000$ scale of selected map sheets in the Eastern Azarbayjan Province of Iran, Final report, Geological map Ghalandar 5467 III SW Explanatory notes. 86 pp. MS Czech Geological Survey, Praha \& Brno.

Popov, S.V., Akhmetiev, M.A., Lopatin, A.V., Bugrova, E.M., Sytchevskaya, E.K., Scherba, I.G., AnDreyeva-GrigoRowich, A.S., Zaporozhets, N.I., Nikolaeva, I.A. \& Kopp, M.L. 2009. Paleogeography and biogeography of Paratethys basins I. Late Eocene-Early Miocene. Trudy Paleontologicheskogo instituta 292, 1-200.

RAJUShKina, G.S. 1968. Iskomaemye khvoinye (sem. Pinaceae) verkhov'ev r. Bukhtarmy [Fossil conifers (fam. Pinaceae) of upper reaches of the Bukhtarma River]. Materialy istorii fauny i flory Kazakhstana, Biologiya i geografiya 4, 8-15, 199-200.

RAJUSHKINA, G.S. 1979. Oligotsenovaya flora Mugodzhar i yuzh- nogo Altaia [Oligocene flora of the Mugodzhar and the southern Altai]. 123 pp. Izdatelstvo Nauka Kazakhstoi SSR, Alma-Ata.

Rapprich, V., Babưrek, J., Bubík, M., Otava, J., Pécskay, Z. \& KRMíČEK, L. 2012. Dvě kontrastní oligocenní vulkanické suity tabrízského vulkanického pásu v okolí města Ahar (Írán). Sborník Západočeského muzea v Plzni, Příroda 116, 17-21.

SCHIMPER, W.P. 1870-1872. Traité de paléontologie végétale 2. 966 pp. Baillière et fils, Paris.

Sснмiтt, H. \& KvaČEK, Z. 1999. Nachweis von Acer aegopodifolium (Goepp.) Baik. ex Iljinskaja in den obermiozänen Indener Schichten des Tagebaues Hambach (Niederzier bei Köln). Documenta naturae 104(3), 83-91.

TANAI, T. 1970. The Oligocene floras from the Kushiro coal field, Hokkaido, Japan. Journal of the Faculty of Science Hokkaido University, Serie IV, Geology and Mineralogy 14(4), 383-514.

WALther, H. 2003. Magnolien in den paläogenen Blattfloren Mitteleuropas. Courier Forschungs-Institutes Senckenberg 241, 131-125.

Walther, H. \& ZaStAWNiAK, E. 2005. Sapindaceae (Aceroideae) from the late Miocene flora of Sośnica near Wrocław - a revision of Göppert's original material and a study of more recent collections. Acta palaeobotanica 45(1), 85-106.

ZhiLIN, S.G. 1974. Tretichnye flory Ustjurta [Tertiary floras of Ustjurt]. 123 pp. Izdatelstvo Nauka, Leningradskoe otdelenie, Leningrad.

ZhiLIN, S.G. 1989. History of the development of the temperate forest flora in Kazakhstan, U.S.S.R. from the Oligocene to Early Miocene. The Botanical Review 55(4), 205-330. 